\title{
Image Building of Political Party of Big Country in New Era
}

\author{
Jianfang Ding ${ }^{1,2}$, Guoxiang Guo² \\ ${ }^{1}$ Wuhan Donghu University, Wuhan, 430070, China \\ ${ }^{2}$ School of Marxism, Wuhan University of Technology, 430070, China
}

Keywords: New era; Communist Party of China; Image construction

\begin{abstract}
Since the beginning of the founding of Communist Party of China, the party attaches great importance to its own image construction and has successfully portrayed many successful images in different historical periods. The 19th CPC National Congress announces China's entry into a new era. The big party in the new era should have "the appearance of the big party". As the world's largest political party, the Communist Party of China needs to create a world party image. It needs more open vision, more enlightened leadership, more pioneering spirit and more generous mind.
\end{abstract}

\section{Introduction}

Since 1921, the Communist Party of China has experienced ninety-six years of development. From fifty people to a ruling party with ninety-six million people, the Communist Party of China has become the largest political party in the world [1]. Following the Communist Party history from small to large and from weak to strong, we can see that from the beginning of the founding of the Communist Party, Chinese attaches great importance to their image building, and created many successful images in different historical periods. During the period of new democratic revolution, our Party led the people in the twenty-eight years of shaping the image of anti-feudal autocratic "revolutionaries"; in the period of the socialist revolution, our Party led people to establish the basic system of socialism, socialist construction, shaping the image of brave "builders" forging ahead ; in the period of reform and opening up, our Party led people to get rid of all obstacles and pave the way for China socialism, shaping the image of "reformers" daring to emancipate the mind in the trend of the times.

The report of 19th CPC National Congress points out that "after a long period of effort, socialism with Chinese characteristics has entered the new era, which is the new historical position of our country." This great argument announces China's entry into the new era. This conclusion gives the party's historical mission and target task with a new connotation of the times. Xi Jinping pointed out that "Great powers and big parties should have a great burden." The Communist Party of China, who is stepping into the new era and opening a new journey, has been trying to win happiness for the Chinese people, contributing to the development of the world and becoming a great political party in the world. The world's political parties need to shape a new image and need more open vision, more enlightened leadership, more pioneering spirit, and more open mind.

\section{More Open Vision to Grasp the Development of the New Media Era}

The Communist Party of China is born in accordance with the trend of the times, and is also developing, growing and mature in the historical process of grasping the pulse of the times. After 96 years of development, profound changes have taken place in the party's ruling task, the ruling environment and the ruling conditions. The world today, with the rapid development of the Internet, has become the most glorious era of human history. We should not only see the new era of China, but also pay attention to the whole era of human social development. We should grasp the bright spirit of the times in a broader and more open world view.

Since April 1994 when Chinese joined the international internet network, the network has developed rapidly [2]. By the end of December 2016, the number of Internet users China 731 million, equivalent to the total population, network communication has become a new media means great 
influence in our country. Compared with traditional media, the new media represented by Internet has realized the diversity of information in the world, breaking the space-time boundary of communication, and more convenient, wider and interactive. The new media not only permeates all aspects of human activities such as economy, politics, culture and social life, but also becomes more and more intimate with the party. "The mass media, from the first day of appearance, has been involved in political and political activities, and it is a tool, means, and way." Media communication is not only an important source of public information, but also an important channel for the political party's image to spread into the public. The active and effective dissemination of new media is conducive to deepening people's understanding, understanding and identification to the party. But the Internet is also a double-edged sword, the people of the new media era are no longer a simple acceptance of information, but also become a disseminator of information. With the help of new media channels, people around the world can be quickly published on the views and opinions of the party, the party's positive and negative image of them all in front of more people. Anything in the reality will be fermented at the first time through the spread of the network.

With the development of the Internet, the western ideology is spreading around the world with a strong cultural attitude, and the emerging media also makes the international ideological struggle more intense. The ideological work of our party has been seriously challenged, and the social and realistic conditions of ideological work have undergone profound changes. The traditional way of sermon, backward propaganda and single communication channels can no longer meet the needs of information dissemination in the new era, but also cause bad impression of "false, big and empty" for the party. The basic predicament of the ruling party's image transmission is the weakening, degradation and marginalization of the tool system, which can't effectively execute the instructions issued by the image communication decision system: or lose control, fail to execute the communication instructions, and cannot undertake the mission of image transmission. In the past, the ruling way of our party was top-down, not open and opaque, and the party in power controlled the right of information. In today's network environment, the people's demand for the right to information continues to expand, and the relationship between the party and the people is more of an interactive relationship. This requires the Communist Party to deepen the understanding of the ruling environment and the ruling conditions with a new vision. In the face of the challenges of the Internet age, the Communist Party wants to build a good image of the people and must adapt to the characteristics of the information network society. In the era of Internet, we must first learn network knowledge, consolidate the guiding position of Marx in the field of ideology and enhance the ideological leadership of the party by using the Internet platform. Secondly, the mass work mechanism and platform of the party in the era of network are innovating. We should rely on the network to build the ruling image of the Communist Party of China and pay attention to the social public opinion function of the network. Finally, to improve the integration of information resources of Party members, strengthen the guidance and management of information transmission, and let the people participate in the communication, and form an effective interaction.

\section{More Enlightened Leadership to Enhance People Happiness Index}

Since the birth of the Communist Party of China, it has taken the responsibility of realizing the people's ownership and led the Chinese people to win one victory after another and achieved the legend of governance in the history of world party politics [3]. To lead the people to create a better life is the goal of our party's unswerving struggle. But after the reform and opening, the unhealthy tendencies, especially the spread of luxury and enjoyment, have seriously eroded the party's advanced nature and purity. Some party members and cadres to "official" superior to the feelings of the masses, indifference, tense relationship with the masses; and some party members work formality, resort to deceit all "image project", and "political project"; more serious is that some cadres of hedonism, money worship, corruption, life style corruption. Since the eighteen Congress, the Central Committee of the Communist Party of China has been fighting against corruption in an unprecedented and severe way. Many corrupt elements have been investigated in accordance with the law. The uprightness of the party is rising, and the social atmosphere is rising. The image of the party and the image of the 
party in the people has undergone historic changes.

A political party, a regime whose destiny depends on the public attitude for or against. The real strength of a country is the strength of the people, and the people of every social class have a sense of pride and happiness. Since the reform and opening, China's traditional social stratum shows new great changes: the number of workers in growing and constantly improve the quality of peasants to non-agricultural transfer; gradually, actively participate in political life; the social status of intellectuals to get bigger promotion, mostly engaged in mental work. There are also several new social classes, such as individuals, intermediaries, freelancers, etc. The nineteen leaders of the party made a major political judgement: the main contradiction of our society has been transformed into the contradiction between people's growing needs of life and imbalance. This puts forward higher and more updated requirements for improving the work of the people's livelihood. The new social contradictions put forward that the party should always stand on the position of most of the people, constantly improve the living standards of the people and enhance the happiness index of the people, to create a political party's image of serving the people heart and soul.

\section{More Pioneering Spirit to Hold High the Socialism Banner with Chinese Characteristics}

China, a country with a history of 5000 years of civilization, has left many brilliant achievements in the long history of history. The compass, gunpowder, printing and paper making have benefited all the world. In the book named Science and Civilizations in China, Joseph Needham, an English man, wrote that "in the ten centuries before the advent of modern science and technology, China's accumulation of technology and knowledge is far more than that of the west." Since the sixteenth century, there are about 300 major scientific and technological inventions affecting human life, of which 175 items are invented by Chinese [4]. Since modern times, due to the conservative backwardness of the feudal rulers and the invasion of the Western powers, China was gradually reduced to a semi colonial and semi feudal society. But the Chinese people, under the leadership of the Communist Party, have overcome one another in the spirit of a hundred percent failure. The Communist Party of China has led the people to accomplish and promote three major events: first, saving the nation; two, rejuvenating the country; three, being a powerful nation. It fundamentally changed the future and destiny of the Chinese nation and lifted the great banner of socialism with Chinese characteristics in the world. History has proved that our party and people are suffering without failure, because we have a strong pioneering spirit, the pioneering spirit is to reform and innovation as the core spirit of the times, is a powerful spiritual force we encourage the. At present, there are some new characteristics of our economic and social development. Facing the new situation, new contradictions and new problems, we need the Communists to keep forging ahead. To build an innovative image of the political party, we should be brave to break all the malpractices of the inopportune ideas and institutional mechanisms. With all the stick to the old ways of thinking the thoughts and behaviors of resolute struggle, the courage to change, innovation, pioneering Chinese characteristics to be more conscious of the mental state of the socialist road.

\section{More Generous Mind to Promote to Build a Human Community with Shared Destiny}

The Communist Party of China not only striving for happiness for the Chinese people, but also for the cause of human progress, which is the sacred mission entrusted by the Communist Party of China and highlights the spirit and tolerance of the Marx political party. In March 2014, general secretary Xi Jinping delivered a speech in Berlin, put forward the "China plan to contribute to improve global governance", and said that China "made contributions to human society in coping with all kinds of challenges in twenty-first Century". In today's world, "no country can deal with the challenges of human beings alone, and no country can return to the isolated island of self." Therefore, only by strengthening cooperation can we meet the challenges together. Of the party since eighteen, put forward the concept of community from the fate of human beings, to promote the "The Belt and Road" construction, to promote the development of the world through Chinese to create more opportunities to deepen their practice by the Communist Party of China to explore the law of 
development of human society, and the successful experience of their own share to the world especially in the developing countries. The Chinese Communists do not "import" foreign models, nor do they "export" the Chinese model, and do not require other countries to copy China. The great historical contribution of the Communist Party of China is of great practical significance and far-reaching historical significance to both China and the world.

At present, our country's comprehensive national strength is increasing, international status is increasing, international influence has been further improved, and the world stage is coming to the center of the world. Looking at the development of the world history, we must contribute to human beings to stand in the center of the stage. The relationship between China and the world has entered a new stage, and the two-major domestic and international situations are closer. The nineteen largest report of the party points out that "we live in a world full of hope and challenge." We cannot give up the dream because of the complexity of the reality, we cannot give up the pursuit because of the ideal distant. In today's world, peace and development are still the theme of the times. The world's multi polarization, economic globalization, social informatization and cultural diversity are developing deeply. All countries are interdependent and interdependent. The trend of peaceful development is irreversible. At the same time, the world is also facing a lot of discordant factors, such as the polarization between the rich and the poor, the lack of economic growth and kinetic energy, the hot issues in the region, the worsening environment, and so on. Therefore, we face many common challenges. In the face of various problems and actively participating in the global challenge, the Communist Party of China needs a more open mind. How to co-ordinate the two-overall situation at home and abroad? How to expand the power of discourse in global governance and how to contribute to the development of the world? All these needs harder work by the Communists and answer with new actions.

\section{References}

[1] Wang Hui. Ruling Legitimacy and the Image Construction of the Ruling Party- A case studyof the Swedish Social Democratic Party [J]. Journal of Henan Normal University (Philosophy and Social Sciences), 2017, 44(6): 23-26.

[2] Liu Qing. Research on Image-building of Chinese Communist Party by Mao Zedong's Thought of Party-Building Theory - Based on the Blueprint of "Correcting Mistaken Ideas in the Party" [J]. Journal of the Party School of Shengli Oil field, 2017, 30(2): 5-8.

[3] Wang Keyuan, Qi Weiping. Party Image Building and the Influence [J]. Chongqing Social Sciences, 2014(2): 76-82.

[4] Fu Qizhang, Kuai Zhengming. Image-building Reference Enlightenment of Political Party and Five missions of CCP [J]. Social Sciences in Xinjiang, 2016(2): 1-5+161. 